\title{
EVALUATION OF THE USE POTENTIAL OF NINE SPECIES OF GENUS Eucalyptus FOR PRODUCTION OF VENEERS AND PLYWOOD PANELS
}

\author{
Setsuo Iwakiri ${ }^{1}$, Jorge Luis Monteiro de Matos ${ }^{1}$, José Guilherme Prata ${ }^{1}$, \\ Rosilani Trianoski², Leandro Soares da Silva ${ }^{3}$
}

(received: February 11, 2011; accepted: January 25, 2013)

\begin{abstract}
The objective of this study was to evaluate the use potential of nine species of Eucalyptus for production of veneer sheets and multilaminated plywood panels. Veneers were cut using a pilot laminating lathe to a nominal thickness of $2.0 \mathrm{~mm}$. Analysis included finding values of overall yield and yield according to three quality classes for the nine relevant species. Plywood panels were manufactured in a laboratory, consisting of five $2.0 \mathrm{~mm}$ veneer sheets which were bonded together with phenol-formaldehyde resin at a weight of $360 \mathrm{~g} / \mathrm{m}^{2}$ (double line). The panels were compressed using a specific pressure of $10 \mathrm{kgf} / \mathrm{cm}^{2}$, a temperature of $140^{\circ} \mathrm{C}$ and a pressing time of 10 minutes. Results indicated that, with the exception of E. phaeotricha and E. pellita, all other Eucalyptus species had above $50 \%$ average veneer yield after lamination. Results of glue line shear testing and static bending parallel and perpendicular demonstrated that species Eucalyptus grandis, Eucalyptus saligna, Eucalyptus dunnii, Eucalyptus globulus, Eucalyptus viminalis, Eucalyptus robusta and Eucalyptus pellita have great potential within the parameters of this study for use in the production of veneer sheets and plywood panels intended for outdoor use.
\end{abstract}

Key words: Veneer sheets, plywood panels, Eucalyptus.

\section{AVALIAÇÃo DO POTENCIAL DE USO DE NOVE ESPÉCIES DO GÊNERO Eucalyptus PARA PRODUÇÃO DE LÂMINAS E COMPENSADOS}

RESUMO: Conduziu-se esta pesquisa, com o objetivo de avaliar o potencial de uso de nove espécies de Eucalyptus na produção de lâminas e painéis compensados multilaminados. As lâminas foram obtidas num torno laminador piloto com espessura nominal de 2,0 mm. Foram obtidos os valores de rendimento total e em três classes de qualidade para as nove espécies estudadas. Os painéis compensados foram produzidos em laboratório, com cinco lâminas de 2,0 mm de espessura, utilizando a resina fenol-formaldeído, com gramatura de $360 \mathrm{~g} / \mathrm{m}^{2}$ (linha dupla). Os painéis foram prensados com pressão especifica de $10 \mathrm{kgf} / \mathrm{cm}^{2}$, temperatura de $140^{\circ} \mathrm{Ce}$ tempo de prensagem de 10 minutos. Os resultados de laminação indicaram que, com exceção de E. phaeotricha e E. pellita, todas as demais espécies de Eucalyptus apresentaram rendimento médio em laminação acima de $50 \%$. Os resultados de ensaios de cisalhamento da linha de cola e flexão estática paralela e perpendicular, demonstraram que as espécies de Eucalyptus grandis, Eucalyptus saligna, Eucalyptus dunnii, Eucalyptus globulus, Eucalyptus viminalis, Eucalyptus robusta e Eucalyptus pellita, apresentam grande potencial dentro dos parâmetros estudados neste trabalho para produção de lâminas e compensados para uso exterior.

Palavras-chave: Lâminas de madeira, compensados, Eucalyptus.

\section{INTRODUCTION}

In Brazil, the timber used for production of plywood panels is both sourced from nonnative forests, whose most common species are Pinus taeda and Pinus elliottii, and from native forests consisting of tropical Amazonian species.

The economic, social and environmental contribution made by the nonnative forest sector is very expressive in Brazil. According to 2008 data, Brazil boasts 6.5 million hectares of nonnative forests, out of which
4.26 million are Eucalyptus and 1.87 million are Pinus forests. This sector contributes around $\mathrm{R} \$ 9$ billion in tax collections and creates 2.2 million direct and indirect jobs. And environmentally speaking, that means seven to ten tons of $\mathrm{CO}_{2}$ being sequestered per hectare/year (SOCIEDADE BRASILEIRA DE SILVICULTURA SBS, 2008).

Figures provided by a study known as Estudo Setorial da Associação Brasileira de Madeira Processada Mecanicamente - ABIMCI (2009) demonstrated that Brazil produced around 2.6 million $\mathrm{m}^{3}$ of plywood in 2008 , out

\footnotetext{
${ }^{1}$ Forest Engineer, Professor PhD in Forest Engineering - Universidade Federal do Paraná/UFPR - Departamento de Engenharia e Tecnologia Florestal - Av. Lothário Meissner, 900, Jardim Botânico - 80.210-170 - Curitiba, PR, Brasil - setsuo@ufpr.br, jmatos@ufpr.br, jgprata@ufpr.br ${ }^{2}$ Industrial Wood Engineer, Professor PhD in Forest Engineering - Universidade Federal do Paraná/UFPR - Departamento de Engenharia e Tecnologia Florestal - Av. Lothário Meissner, 900, Jardim Botânico - 80.210-170 - Curitiba, PR, Brasil - rosillani@gmail.com

${ }_{3}^{3}$ Industrial Wood Engineer - Universidade Federal do Paraná/UFPR - Av. Lothário Meissner, 900, Jardim Botânico - 80.210-170 - Curitiba, PR, Brasil-1bss_88@hotmail.com
} 
of which 2.0 million $\mathrm{m}^{3}$ were produced with species from nonnative forests (Pinus spp.), against 0.60 million $\mathrm{m}^{3}$ produced with species from native forests (tropical woods). Figures demonstrated that around $70 \%$ of these plywood panels are produced with Pinus sourced from forest stands. Extensive exploitation of traditional Pinus species (Pinus taeda and Pinus elliottii) has created problems relating to supply of timber from large-diameter trees with which to derive good quality veneers for production of plywood panels.

Several studies have been conducted in search for alternative species, looking to increase the supply of quality timber for production of veneers and plywood panels. Some studies conducted by Brazilian researchers and involving Eucalyptus species for veneer and plywood production are reported below.

Jankowski (1979) was a pioneer in the study of veneer cutting and plywood production in Brazil. This author used wood from Eucalyptus grandis, E. saligna and E. urophylla and found good results with E. grandis for veneering and plywood production. Jankowski and Aguiar (1983) evaluated the species Eucalyptus saligna, E. grandis, E. triantha, E. microcorys and E. pellita at age 10 years for veneer cutting and plywood production, and concluded that only E. triantha and E. saligna offered acceptable quality veneers which were suitable for manufacture of plywood panels.

Keinert Júnior and Interanmense (1994) studied the behavior of six species of genus Eucalyptus in production of veneers and plywood panels and found good results in their qualitative material assessments. Similarly, Interanmense (1998) and Pio (1996) studied the behavior of four Eucalyptus species for production of plywood panels intended for exterior use and found positive results regarding their mechanical properties.

Bortoletto Júnior (2003) evaluated the behavior of 11 species of genus Eucalyptus for production of plywood panels and concluded that the following species are suitable for production of plywood for exterior use: Eucalyptus pilularis, E. propingua, E. microcorys, E. maculata, E. pyrocarpa, E. tereticornis, E. urophylla, E. pellita, E. torelliana and E. saligna.

Iwakiri et al. (2007) studied the properties of structural panels from Eucalyptus grandis and Eucalyptus dunnii as manufactured with different formulations and concluded that both species comply with minimum requirements set in standard EN 314 (EUROPEAN COMMITTEE FOR STANDARDIZATION - EN, 1993) concerning glue line strength in panels intended for exterior use. These authors also found that variations in the amount of glue being used did not significantly influence the mechanical properties of resulting plywood panels.

As far as plywood production is concerned, technological factors should be analyzed carefully, in particular those concerning the physicochemical process involved in bonding veneer sheets (MARRA, 1992). The choice of resin to be used in veneer bonding should consider suitability for the end environment, more specifically urea-formaldehyde should be used for interior applications while phenol-formaldehyde should be used for exterior applications. Parameters such as formulation and quantity of adhesive will directly influence not only the bonding quality but also the production cost of plywood panels (BALDWIN, 1993; SELLERS, 1993). These authors argue that wood density is a critical factor in defining these parameters, given the interactions that occur between wood porosity and glue absorption to finally form an adhesive bond between the veneer sheets. According to Marra (1992), low-density woods absorb larger quantities of adhesive, on account of their high porosity. In such cases, adhesive viscosity should be increased in order to avoid excessive glue line absorption due to porosity. Other factors such as $\mathrm{pH}$ and extractives content are also critical as they may affect adhesive curing during the hot-press process. Baldwin (1993) argues that some extractives present in veneers may obstruct the vaporization process and migration from one glue line to another, and then to the edges of the panel. This process being very slow will result in increased vapor pressure within, resulting in a burst at the time the press is opened and consequently in a delamination of the panel. Therefore, heterogeneity and variability in the anatomical, physical and chemical properties of wood, whether among species or among different parts of a single tree, indeed may affect the bonding conditions of veneer sheets during the manufacturing process of plywood.

This study aimed to evaluate the use potential of nine species of genus Eucalyptus for production of veneers and plywood panels intended for exterior use.

\section{MATERIAL AND METHODS}

The following species were used in this research: Eucalyptus grandis, Eucalyptus saligna, Eucalyptus dunnii, Eucalyptus globulus, Eucalyptus viminalis, Eucalyptus robusta, Eucalyptus phaeotricha, Eucalyptus deanei and Eucalyptus pellita. At the time of sample

Cerne, Lavras, v. 19, n. 2, p. 263-269, abr./jun. 2013 
collection, the first two above species were 21 years and the other species were 18 to 19 years. Two trees of each species were sampled from forest stands located in the region of Piên - PR and Jaraguá do Sul - SC. For bonding the veneer sheets a phenol-formaldehyde resin (FF) was used with a solids content of $49 \%$, a $\mathrm{pH}$ of 11.5 and Brookfield viscosity of $420 \mathrm{cP}$.

Each tree was bucked into three $\operatorname{logs} 0.60 \mathrm{~m}$ in length each, to a total of six logs per species prior to veneer cutting. Veneers were obtained using a pilot lathe to a thickness of $2.0 \mathrm{~mm}$ and divided using a pneumatic guillotine so as to obtain $600 \mathrm{~mm}$ x $600 \mathrm{~mm}$ pieces. Samples $20 \mathrm{~mm}$ x $300 \mathrm{~mm}$ in size were randomly taken from veneers of each species for determination of apparent specific mass, using a total of 20 test pieces per species.

Veneers were graded as A, B and C, according to requirements specified in standard ABNT 31:000.05001/1 (ASSOCIAÇÃO BRASILEIRA DE NORMAS TÉCNICAS - ABNT, 1986). Also determined were the proportions of veneers in each of the three quality classes contributing to the overall yield per species. Veneer yield per species was determined by the ratio of produced veneer volume to log volume without bark. Determinations were made of total yield and yield per quality class for each species being studied, as well as of veneer surface evenness after drying.

Prior to being assembled, the veneer sheets were oven-dried to an average moisture content of $8 \%$ and finally cut to a square shape $500 \mathrm{~mm}$ x $500 \mathrm{~mm}$ in size. Each panel was made with five veneers using phenolformaldehyde resin with the following formulation, in parts by weight: resin $=100 \mathrm{p} / \mathrm{w}$, wheat flour $=15 \mathrm{p} / \mathrm{w}$ and water $=15 \mathrm{p} / \mathrm{w}$. Adhesive was applied manually at a rate of $360 \mathrm{~g} / \mathrm{m}^{2}$ (double line), using a spatula across the surface of the veneer. The panels were compressed using a specific pressure of $10 \mathrm{kgf} / \mathrm{cm}^{2}$, a temperature of $140^{\circ} \mathrm{C}$ and a pressing time of 10 minutes. Two panels were produced per species, to a total of 18 experimental panels.

After keeping the panels in a temperaturecontrolled chamber set at a temperature of $20 \pm 2{ }^{\circ} \mathrm{C}$ and relative humidity of $65 \pm 5 \%$, test pieces were taken and submitted to the following laboratory tests: glue line strength to shear stress (dry test, boil/dry cycle and 72-h boil) and static bending for determining the modulus of elasticity (MOE) and modulus of rupture (MOR) parallel and perpendicular to panel plane. Tests were performed according to procedures described in European Standards
EN 314 and EN 320 respectively. Test results were examined using analysis of variance and Tukey test at the $95 \%$ probability level, outlining a completely randomized design.

\section{RESULTS AND DISCUSSION}

\subsection{Apparent specific mass of veneers}

Mean values of apparent specific mass for the veneers of each species are illustrated in Table 1.

Table 1 - Apparent specific mass of veneers.

Tabela 1 - Massa especifica aparente das lâminas.

\begin{tabular}{lc}
\hline Species & $\begin{array}{c}\text { Apparent specific mass } \\
\left(\mathrm{g} / \mathrm{cm}^{3}\right)\end{array}$ \\
\hline Eucalyptus grandis & 0.436 \\
Eucalyptus saligna & 0.687 \\
Eucalyptus globulus & 0.564 \\
Eucalyptus viminalis & 0.617 \\
Eucalyptus dunnii & 0.561 \\
Eucalyptus robusta & 0.577 \\
Eucalyptus phaeotricha & 0.584 \\
Eucalyptus deanei & 0.571 \\
Eucalyptus pellita & 0.597 \\
\hline
\end{tabular}

As can be noted, mean values of apparent specific mass ranged from $0.436 \mathrm{~g} / \mathrm{cm}^{3}$ for veneers of Eucalyptus grandis to $0.687 \mathrm{~g} / \mathrm{cm}^{3}$ for Eucalyptus saligna. These values fall within the medium to low range of reference values reported in literature and thus can be considered suitable for manufacture of plywood.

In a study with 11 Eucalyptus species, Bortoletto Júnior (2003) found the following mean values of basic density: E. pilulararis $-0.67 \mathrm{~g} / \mathrm{cm}^{3}$, E. propinqua -0.77 $\mathrm{g} / \mathrm{cm}^{3}$, E. microcorys $-0.63 \mathrm{~g} / \mathrm{cm}^{3}$, E. maculata $-0.71 \mathrm{~g} /$ $\mathrm{cm}^{3}$, E. pyrocarpa $-0.64 \mathrm{~g} / \mathrm{cm}^{3}$, E. tereticornis $-0.74 \mathrm{~g} /$ $\mathrm{cm}^{3}$, E. urophylla $-0.60 \mathrm{~g} / \mathrm{cm}^{3}$, E. pellita $-0.65 \mathrm{~g} / \mathrm{cm}^{3}$, E. citriodoroa $-0.76 \mathrm{~g} / \mathrm{cm}^{3}$, E. torelliana $-0.61 \mathrm{~g} / \mathrm{cm}^{3}, E$. saligna $-0.56 \mathrm{~g} / \mathrm{cm}^{3}$. In a study with veneers of Eucalyptus cloeziana, Eucalyptus punctata and Eucalyptus maculate, Interanmense (1998) found mean values of basic density of $0.70,0.76$ and $0.78 \mathrm{~g} / \mathrm{cm}^{3}$ respectively. And Pio (1996) found basic density values of 0.64 and $0.56 \mathrm{~g} / \mathrm{cm}^{3}$ for veneers of Eucalyptus scabra and Eucalyptus robusta respectively.

Cerne, Lavras, v. 19, n. 2, p. 263-269, abr./jun. 2013 


\subsection{Yields in the lamination process / veneer quality}

Yield results in the lamination process, both overall and by quality class, are given in Table 2 .

Table 2 - Lamination yield and veneer quality.

Tabela 2 - Rendimento em laminação e qualidade das lâminas.

\begin{tabular}{lccrrc}
\hline Species & RT & A & \multicolumn{1}{c}{$\mathrm{B}$} & \multicolumn{1}{c}{ C } & QS \\
\hline Eucalyptus grandis & 50.31 & 0.88 & 9.90 & 39.53 & SO \\
Eucalyptus saligna & 67.22 & 0.00 & 1.39 & 65.83 & SO \\
Eucalyptus globulus & 58.39 & 0.00 & 25.28 & 33.10 & $\mathrm{MO}$ \\
Eucalyptus viminalis & 55.95 & 2.43 & 45.22 & 8.30 & $\mathrm{MO}$ \\
Eucalyptus dunnii & 55.52 & 0.71 & 7.52 & 47.29 & $\mathrm{PO}$ \\
Eucalyptus robusta & 54.53 & 0.00 & 40.34 & 14.19 & $\mathrm{PO}$ \\
$\begin{array}{l}\text { Eucalyptus } \\
\text { phaeotricha }\end{array}$ & 41.37 & 0.00 & 15.11 & 26.26 & $\mathrm{PO}$ \\
$\begin{array}{l}\text { Eucalyptus deanei } \\
\text { Eucalyptus pellita }\end{array}$ & 50.02 & 0.00 & 31.85 & 18.16 & $\mathrm{MO}$ \\
\hline
\end{tabular}

RT: overall yield; QS: quality of veneer surface (after dry); SO: no undulation; PO: few undulations; MO: many undulations.

Mean values of overall lamination yield, for each of the nine Eucalyptus species, ranged from $41.37 \%$ for $E$. phaeotricha to $67.22 \%$ for $E$. saligna. With the exception of E. phaeotricha and E. pellita, all other species had mean lamination yields above $50 \%$. As regards veneer quality, only three species, namely E. grandis, E. viminalis and E. dunnii, derived superior quality veneers (A), despite the percentages below 3\%. Higher percentages of class B veneers were found for E. viminalis (45.22\%) and $E$. robusta $(40.34 \%)$. As for class $\mathrm{C}$, higher percentages of class $\mathrm{C}$ veneers were found for E. saligna and E. dunni, with $65.83 \%$ and $47.29 \%$ respectively.

Results found in this study are satisfactory in comparison with values of lamination yield reported in literature for Eucalyptus species. While studying clones I and II of Eucalyptus grandis x Eucalyptus urophylla, Almeida et al. (2004) found mean yields of $51.74 \%$ and $56.81 \%$ respectively. Pio (1996) found mean yields of $36.47 \%$ and $44.00 \%$ for species E. scabra and E. robusta respectively. This author cites, as sources for comparison, mean yields for the following species: Pinus elliottii (42.40\% and 55.50\%), Pinus strobus $(54.40 \%)$ and $E$. robusta (49.10\%). Interanmense (1998) found mean yields of $50.00 \%, 50.43 \%$ and $44.86 \%$ for species E. viminalis, E. cloeziana and E. maculata respectively.

Cerne, Lavras, v. 19, n. 2, p. 263-269, abr./jun. 2013

\subsection{Glue line strength to shear stress testing}

Results of glue line strength to shear testing on panels are illustrated in Table 3.

Table 3 - Glue line strength to shear stress testing.

Tabela 3 - Cisalhamento da linha de cola.

\begin{tabular}{|c|c|c|c|c|c|c|}
\hline \multirow{2}{*}{ Species } & \multicolumn{2}{|c|}{ Dry (MPa) } & \multicolumn{2}{|c|}{ Cycle (MPa) } & \multicolumn{2}{|c|}{$\begin{array}{c}\text { 72-h Boil } \\
(\mathrm{MPa})\end{array}$} \\
\hline & $\begin{array}{l}\text { Mean } \\
(\mathrm{CV})\end{array}$ & $\begin{array}{l}\text { FM } \\
(\%)\end{array}$ & $\begin{array}{l}\text { Mean } \\
(\mathrm{CV})\end{array}$ & $\begin{array}{l}\text { FM } \\
(\%)\end{array}$ & $\begin{array}{l}\text { Mean } \\
(\mathrm{CV})\end{array}$ & $\begin{array}{l}\text { FM } \\
(\%)\end{array}$ \\
\hline E. grandis & $\begin{array}{c}2.72 \mathrm{a} \\
(20.99)\end{array}$ & 82 & $\begin{array}{l}1.41 \mathrm{bc} \\
(15.89)\end{array}$ & 27 & $\begin{array}{c}1.73 \mathrm{a} \\
(28.47)\end{array}$ & 69 \\
\hline E. saligna & $\begin{array}{c}2.05 \mathrm{~b} \\
(16.17)\end{array}$ & 23 & $\begin{array}{c}1.82 \mathrm{a} \\
(19.50)\end{array}$ & 13 & $\begin{array}{l}1.54 \mathrm{ab} \\
(32.83)\end{array}$ & 22 \\
\hline $\begin{array}{l}\text { E. } \\
\text { globulus }\end{array}$ & $\begin{array}{l}2.00 \mathrm{~b} \\
(6.29)\end{array}$ & 22 & $\begin{array}{c}1.38 \mathrm{bcd} \\
(16.84)\end{array}$ & 4 & $\begin{array}{l}1.21 \mathrm{bc} \\
(25.10)\end{array}$ & 3 \\
\hline $\begin{array}{l}E . \\
\text { viminalis }\end{array}$ & $\begin{array}{c}2.78 \mathrm{a} \\
(10.47)\end{array}$ & 30 & $\begin{array}{l}1.54 \mathrm{ab} \\
(11.01)\end{array}$ & 11 & $\begin{array}{c}1.86 \mathrm{a} \\
(11.33)\end{array}$ & 19 \\
\hline E. dunnii & $\begin{array}{l}1.79 \mathrm{bc} \\
(16.07)\end{array}$ & 11 & $\begin{array}{l}1.08 \text { ef } \\
(20.63)\end{array}$ & 3 & $\begin{array}{c}0.86 \mathrm{c} \\
(18.58)\end{array}$ & 1 \\
\hline $\begin{array}{l}\text { E. } \\
\text { robusta }\end{array}$ & $\begin{array}{l}2.29 \mathrm{ab} \\
(16.22)\end{array}$ & 9 & $\begin{array}{c}0.81 \mathrm{f} \\
(19.37)\end{array}$ & 0 & $\begin{array}{c}1.08 \mathrm{c} \\
(22.53)\end{array}$ & 3 \\
\hline $\begin{array}{l}\text { E. } \\
\text { phaotrica }\end{array}$ & $\begin{array}{l}2.13 \mathrm{~b} \\
(22.56)\end{array}$ & 41 & $\begin{array}{c}1.09 \mathrm{def} \\
(7.35)\end{array}$ & 7 & $\begin{array}{c}1.00 \mathrm{c} \\
(36.97)\end{array}$ & 11 \\
\hline E. deanei & $\begin{array}{c}1.37 \mathrm{c} \\
(13.85)\end{array}$ & 23 & $\begin{array}{c}1.32 \text { bcde } \\
(9.79)\end{array}$ & 17 & $\begin{array}{c}0.91 \mathrm{c} \\
(17.86)\end{array}$ & 5 \\
\hline E. pellita & $\begin{array}{c}1.99 \mathrm{~b} \\
(14.46)\end{array}$ & 42 & $\begin{array}{l}1.12 \mathrm{cde} \\
(22.98)\end{array}$ & 13 & $\begin{array}{l}1.18 b c \\
(11.90)\end{array}$ & 15 \\
\hline
\end{tabular}

$\mathrm{CV}$ : coefficient of variation; FM: percentage of wood defects; Means followed by the same letter in a column are statistically similar at the $95 \%$ probability level.

In the dry test, the mean values of shear stress ranged from 1.37 MPa for E. deanei to $2.78 \mathrm{MPa}$ for $E$. viminalis. The mean values found for panels made from E. viminalis were statistically similar to values found for panels made from E. grandis and E. robusta but higher in comparison with panels made from the remaining Eucalyptus species.

In the boil cycle test, the mean values of shear stress ranged from $0.81 \mathrm{MPa}$ for $E$. robusta to $1.82 \mathrm{MPa}$ for $E$. saligna. Panels made from $E$. saligna had statistically similar mean values to panels made from $E$. viminalis but higher values in comparison with the remaining Eucalyptus species.

As for the 72-hour boil test, the mean values of shear stress ranged from $0.86 \mathrm{MPa}$ for $E$. dunnii to 1.86 
$\mathrm{MPa}$ for E. viminalis. Panels made from E. viminalis had statistically similar mean values to panels made from $E$. grandis and E. saligna but higher values in comparison with panels made from the remaining Eucalyptus species.

Except for species E. robusta, E. dunnii and $E$. deanei, the mean values of shear stress found for panels from all other species, both in the boil cycle test and in the 72-hour boil test, were found to be above the minimum value of 1.0 MPa defined by standard EN 314-2 (EN, 1993) as being a requirement for panels intended for exterior use.

Results of glue line strength to shear stress found in this study for all nine Eucalyptus species can be considered satisfactory in relation to reference values reported in literature. Iwakiri et al. (2007) studied phenolic plywood panels produced with veneers from $E$. grandis and $E$. dunnii and found mean values of shear stress of $2.69 \mathrm{MPa}$ and $2.43 \mathrm{MPa}$ in the dry test, against $1.57 \mathrm{MPa}$ and 1.20 $\mathrm{MPa}$ in the boil cycle test, respectively for each of the two species. Bortoletto Júnior (2003) studied 11 species of Eucalyptus and found mean values of shear stress in the range of $1.9 \mathrm{MPa}$ to $2.4 \mathrm{MPa}$ in the boil cycle test.

\subsection{Static bending parallel}

Test results of static bending in the parallel direction are illustrated in Table 4.

The range of variation in mean values of $\mathrm{MOE}$ parallel was 9,378 MPa for panels made from $E$. deane $i$ and 18,494 MPa for panels made from E. dunnii. Regarding MOR parallel, variation ranged from 72.23 MPa for panels made from $E$. deanei and $115.68 \mathrm{MPa}$ for E. viminalis.

The mean values of MOE parallel found for panels from E. dunnii, E. viminalis and E. saligna were statistically higher in comparison with panels made from other species of Eucalyptus. As for MOR parallel, the mean values found for panels from $E$. viminalis were statistically similar in relation to panels from E. dunnii, E. saligna, E. phaeotricha and E. globules but higher in relation to panels from other Eucalyptus species.

With reference to results reported in literature, Iwakiri et al. (2007) found 11,058 MPa and 12,699 $\mathrm{MPa}$ as mean values of MOE parallel, against $83.70 \mathrm{MPa}$ and $77.50 \mathrm{MPa}$ as mean values of MOR parallel, for plywood panels made from E. grandis and E. dunnii respectively. Bortoletto Júnior (2003), in a study with 11 species of Eucalyptus, found mean values of MOE parallel in the range of $12,336 \mathrm{MPa}$ to $19,331 \mathrm{MPa}$, against mean values of MOR parallel in the range of $84 \mathrm{MPa}$ to $130 \mathrm{MPa}$.
Table 4 - Static bending parallel.

Tabela 4 - Flexão estática paralela.

\begin{tabular}{lcccc}
\hline \multirow{2}{*}{\begin{tabular}{l} 
Species \\
\cline { 2 - 5 }
\end{tabular}} & \multicolumn{2}{c}{ MOE $(\mathrm{MPa})$} & \multicolumn{2}{c}{ MOR $(\mathrm{MPa})$} \\
\hline $\begin{array}{l}\text { Eucalyptus } \\
\text { grandis }\end{array}$ & $12,251 \mathrm{~b}$ & 10.09 & $91.29 \mathrm{bc}$ & 8.62 \\
$\begin{array}{l}\text { Eucalyptus } \\
\text { saligna }\end{array}$ & $17,379 \mathrm{a}$ & 10.49 & $106.61 \mathrm{ab}$ & 22.41 \\
$\begin{array}{l}\text { Eucalyptus } \\
\text { globulus }\end{array}$ & $12,987 \mathrm{~b}$ & 7.78 & $96.38 \mathrm{ab}$ & 10.22 \\
$\begin{array}{l}\text { Eucalyptus } \\
\text { viminalis }\end{array}$ & $17,523 \mathrm{a}$ & 4.67 & $115.68 \mathrm{a}$ & 5.88 \\
$\begin{array}{l}\text { Eucalyptus } \\
\text { dunnii }\end{array}$ & $18,494 \mathrm{a}$ & 8.76 & $113.87 \mathrm{a}$ & 6.53 \\
$\begin{array}{l}\text { Eucalyptus } \\
\text { robusta }\end{array}$ & $13,285 \mathrm{~b}$ & 9.01 & $91.15 \mathrm{bc}$ & 10.37 \\
$\begin{array}{l}\text { Eucalyptus } \\
\text { phaotrica }\end{array}$ & $13,754 \mathrm{~b}$ & 7.42 & $106.28 \mathrm{ab}$ & 9.94 \\
$\begin{array}{l}\text { Eucalyptus } \\
\text { deanei }\end{array}$ & $9,378 \mathrm{c}$ & 4.83 & $72.23 \mathrm{c}$ & 13.17 \\
$\begin{array}{l}\text { Eucalyptus } \\
\text { pellita }\end{array}$ & $12,450 \mathrm{~b}$ & 6.98 & $90.37 \mathrm{bc}$ & 9.52 \\
\hline
\end{tabular}

MOE: modulus of elasticity; MOR: modulus of rupture; CV: coefficient of variation; Means followed by the same letter in a column are statistically similar at the $95 \%$ probability level.

Therefore, it can be said that results found in this study in static bending parallel testing for all nine species of Eucalyptus are considered satisfactory.

The mean values of MOE and MOR in the parallel direction found in this study for all nine Eucalyptus species fully comply with the minimum requirements established in standard DIN 68792 (DEUTSHE INSTITUT FÜR NORMUNG - DIN, 1979) for plywood panels intended for exterior use - concrete moulds, whose values are 5,000 $\mathrm{MPa}$ for MOE and $45 \mathrm{MPa}$ for MOR.

\subsection{Static bending perpendicular}

Results of static bending tests in the perpendicular direction are illustrated in Table 5.

The range of variation in mean values of MOE perpendicular was $2,738 \mathrm{MPa}$ for panels made from $E$. deanei and 4,627 $\mathrm{MPa}$ for panels from E. viminalis. For MOR perpendicular, variation ranged from $34.46 \mathrm{MPa}$ for panels made from $E$. deanei to $53.43 \mathrm{MPa}$ for $E$. viminalis. As was expected, values of MOE and MOR in the perpendicular direction were much lower in relation to values found for the parallel direction.

Cerne, Lavras, v. 19, n. 2, p. 263-269, abr./jun. 2013 
Table 5 - Static bending perpendicular.

Tabela 5 - Flexão estática perpendicular.

\begin{tabular}{|c|c|c|c|c|}
\hline \multirow{2}{*}{ Species } & \multicolumn{2}{|c|}{$\operatorname{MOE}(\mathrm{MPa})$} & \multicolumn{2}{|c|}{$\operatorname{MOR}(\mathrm{MPa})$} \\
\hline & Mean & CV $(\%)$ & Mean & CV $(\%)$ \\
\hline $\begin{array}{l}\text { Eucalyptus } \\
\text { grandis }\end{array}$ & $3,801 \mathrm{bc}$ & 18.46 & $46.14 \mathrm{ab}$ & 16.64 \\
\hline $\begin{array}{l}\text { Eucalyptus } \\
\text { saligna }\end{array}$ & $4,305 \mathrm{ab}$ & 10.94 & $53.43 \mathrm{a}$ & 8.13 \\
\hline $\begin{array}{l}\text { Eucalyptus } \\
\text { globulus }\end{array}$ & $3,383 \mathrm{~cd}$ & 11.16 & $43.79 \mathrm{bc}$ & 8.32 \\
\hline $\begin{array}{l}\text { Eucalyptus } \\
\text { viminalis }\end{array}$ & $4,627 \mathrm{a}$ & 1.38 & $46.67 \mathrm{ab}$ & 3.86 \\
\hline $\begin{array}{l}\text { Eucalyptus } \\
\text { dunnii }\end{array}$ & $3,978 a b c$ & 9.25 & $41.98 \mathrm{bc}$ & 6.38 \\
\hline $\begin{array}{l}\text { Eucalyptus } \\
\text { robusta }\end{array}$ & $3,935 \mathrm{abc}$ & 3.99 & $45.46 \mathrm{ab}$ & 1.85 \\
\hline $\begin{array}{l}\text { Eucalyptus } \\
\text { phaotrica }\end{array}$ & $3,690 \mathrm{bc}$ & 14.03 & $45.67 \mathrm{ab}$ & 13.72 \\
\hline $\begin{array}{l}\text { Eucalyptus } \\
\text { deanei }\end{array}$ & $2,738 \mathrm{~d}$ & 6.33 & $34.46 \mathrm{c}$ & 16.52 \\
\hline $\begin{array}{l}\text { Eucalyptus } \\
\text { pellita }\end{array}$ & $3,616 \mathrm{bc}$ & 14.23 & $39.44 \mathrm{bc}$ & 17.58 \\
\hline
\end{tabular}

MOE: modulus of elasticity; MOR: modulus of rupture; $\mathrm{CV}$ : coefficient of variation; Means followed by the same letter in a column are statistically similar at the $95 \%$ probability level.

The mean values of MOE perpendicular found for panels from $E$. viminalis were statistically similar in relation to panels from E. saligna, E. dunnii and E. robusta but higher in relation to panels from other Eucalyptus species. As regards MOR perpendicular, the mean values found for panels from $E$. saligna were statistically similar in relation to panels from E. viminalis, E. phaeotricha and $E$. robusta but higher in relation to panels from other Eucalyptus species.

Results of MOE and MOR perpendicular are rarely reported in literature. Yet, if confronted with results reported by Bortoletto Júnior (2003) for 11 species of Eucalyptus, the values found in this study can be considered satisfactory. The mean values found by the above author for MOE perpendicular ranged from 3,419 $\mathrm{MPa}$ to $5,487 \mathrm{MPa}$, while for MOR perpendicular the values ranged from $46 \mathrm{MPa}$ to $64 \mathrm{MPa}$.

The mean values of MOE and MOR in the perpendicular direction found in this study for all nine
Eucalyptus species fully comply with the minimum requirements established in standard DIN 68792 (DIN, 1979) for plywood panels intended for exterior use concrete moulds, whose values are 2,500 MPa for MOE and $30 \mathrm{MPa}$ for MOR.

\section{CONCLUSIONS}

Results found in this study led to the following conclusions:

- The mean values of apparent specific mass found for all nine Eucalyptus species fell within the medium to low range, indicating suitability for production of veneers and plywood panels.

- With the exception of E. phaeotricha and $E$. pellita, all other Eucalyptus species had average lamination yields above $50 \%$.

- With the exception of E. robusta, E. dunnii and E. deanei, panels made from all other Eucalyptus species had mean values of shear stress above the minimum of 1.0 MPa established by standard EN 314-2:1993 as being a requirement for panels intended for exterior use.

- The mean values of MOE and MOR, parallel and perpendicular, as found for all nine Eucalyptus species, comply with the minimum requirements established in standard DIN 68792 (DIN, 1979) for panels intended for exterior use.

- Based on results, it can be said that species Eucalyptus grandis, Eucalyptus saligna, Eucalyptus dunnii, Eucalyptus globulus, Eucalyptus viminalis, Eucalyptus robusta and Eucalyptus pellitai have great use potential for production of veneers and plywood panels intended for exterior use.

- Species Eucalyptus viminalis was found to provide the best results in all tests.

\section{REFERENCES}

ALMEIDA, R. R.; BORTOLETTO JÚNIOR, G.; JANKOWSKI, I. P. Produção de lâminas a partir da madeira de clones do híbrido Eucalyptus grandis $x$ Eucalyptus urophylla. Scientia Forestalis, Piracicaba, n. 65, p. 49-58, 2004.

ASSOCIAÇÃO BRASILEIRA DE MADEIRA PROCESSADA MECANICAMENTE. Estudo setorial 2009. São Paulo, 2009. 45 p.

ASSOCIAÇÃO BRASILEIRA DE NORMAS TÉCNICAS. NBR 31:000.05-001/1: chapas de madeira compensada. Rio de Janeiro, 1986.

Cerne, Lavras, v. 19, n. 2, p. 263-269, abr./jun. 2013 
BALDWIN, R. F. Plywood and veneer-based products: manufacturing practices. San Francisco: M. Freeman, 1993. $388 \mathrm{p}$.

BORTOLETTO JÚNIOR, G. Produção de compensados com 11 espécies do gênero Eucalyptus, avaliação das suas propriedades físico-mecânicas e indicações para utilização. Scientia Forestalis, Piracicaba, v. 63, p. 65-78, jun. 2003.

DEUTSHE INSTITUT FÜR NORMUNG. Large srea shuttering panels of veneer plywood for concrete and reinforced concrete. Berlin: Beuth Verlag, 1979.

EUROPEAN COMMITTEE FOR STANDARDIZATION. EN 314-2: plywood: determination of shear bonding strength. Geneva, 1993.

INTERAMNENSE, M. T. Utilização das madeiras de Eucalyptus cloeziana (F. Muell), Eucalyptus maculata (Hook) e Eucalyptus puctata DC var. punctata para produção de painéis compensados. 1998. 81 p. Dissertação (Mestrado em Engenharia Florestal) - Universidade Federal do Paraná, Curitiba, 1998.

IWAKIRI, S.; KEINERT JUNIOR, S.; PRATA, J. G.; ROSSO, S. Produção de painel compensado estrutural de Eucalyptus grandis e Eucalyptus dunnii. Floresta, Colombo, v. 37, n. 3, p. 363-367, 2007.
JANKOWSKI, I. P. Manufatura de painéis compensados com madeira de Eucalyptus spp: resultados preliminares. Piracicaba: IPEF, 1979. 4 p. (Circular Técnica IPEF, 82).

JANKOWSKI, I. P.; AGUIAR, O. J. R. Manufatura de painéis compensados com Eucalyptus: caracterização de diversas espécies. Floresta, Colombo, v. 14, n. 1, p. 46-53, 1983.

KEINERT JÚNIOR, S.; INTERAMNENSE, M. T. Laminação, produção e testes de compensados a partir de Eucalyptus spp: relatório de projeto de pesquisa apresentado ao CNPq. Curitiba: UFPR, 1994. 94 p.

MARRA, A. A. Technology of wood bonding: principles in practice. New York: V. N. Reinhold, 1992. 453 p.

PIO, N. S. Avaliação da madeira de Eucalyptus scabra (Dum-Cours) e Eucalyptus robusta (Smith) na produção de painéis compensados. 1996. 101 f. Dissertação (Mestrado em Engenharia Florestal) - Universidade Federal do Paraná, Curitiba, 1996.

SELLERS, T. Plywood and adhesive technology. New York: M. Dekker, 1993. 661 p.

SOCIEDADE BRASILEIRA DE SILVICULTURA. Fatos e números do Brasil florestal. São Paulo, 2008. Disponível em: $<$ http://www.sbs.org.br>. Acesso em: 31 jan. 2011.

Cerne, Lavras, v. 19, n. 2, p. 263-269, abr./jun. 2013 
